\title{
Performance of Teak (Tectona grandis L.F) wood on exposure to outdoor weather conditions
}

\author{
${ }^{1}$ IZEKOR, D N; ${ }^{2}$ FUWAPE, J A \\ ${ }^{1}$ Department of Forestry and Wildlife, University of Benin, P.M.B.1154, Benin City, Nigeria \\ ${ }^{2}$ Department of Forestry and Wood Technology, Federal University of Technology, P.M.B. 704, \\ Akure, Nigeria
}

\begin{abstract}
The performance of Teak wood on exposure to outdoor weather conditions was investigated. Six even age trees of similar class diameter comprising 15, 20 and 25- year old Teak wood respectively were studied. Wood samples were collected from three points along the tree radial and longitudinal positions. Percentage shrinkage of weathered Teak increased from the tree base to the top and also from the inner wood to the outer wood for the three age classes. It however decreased with increase in the age of the tree. The mean percentage shrinkage of weathered Teak obtained in the radial directions were $1.51,1.30$ and $0.73 \%$ while in the tangential directions, the mean value obtained were $3.14,2.23$ and $1.27 \%$ for ages 15,20 and 25 - year old Teak wood respectively. The results of the visual observation of the study samples showed that Teak wood on exposure to outdoor weather condition was resistant to surface splitting and checking in both radial and tangential directions. Discolouration and loss of brightness was observed for all the study samples on exposure to outdoor weather conditions irrespective of the tree age and the positions from where the wood sample was collected. Plantation grown Tectona grandis wood of older age classes in Edo State has higher resistance to shrinkage, surface splitting and checking. Its wood is therefore recommended for use as structural material in outdoor weather conditions @JASEM
\end{abstract}

Key words: Teak wood, outdoor weather condition, percentage shrinkage, surface splitting, surface checking, discolouration, loss of brightness.

Wood is a naturally durable material that has long been recognized for its versatile and attractive structural properties (Feist, 1990). It is widely applied as industrial raw materials for construction purposes but deteriorate on continued exposure to outdoor conditions (de la Caba et al, 2007). Wood materials are vulnerable to harmful physical and chemical effects of the environment (Mahmoud et al, 2001). Various physical and mechanical properties are affected by weathering such as loss of gloss, yellowing colour change, adhesion of layers, peeling, chalking, splitting and checking. Correlation of changes of selected properties under accelerated test serves for predicting service durability (de la Caba $e t$ $a l, 2007)$. The surface durability of any material is its resistance to undesirable changes caused by the natural environment to which it is exposed during its service life. The main constituents of the environment which cause weathering or degradation are sunlight, UV radiation, temperature, oxygen, water and pollutants. Among the above factors, it has been found that sunlight, that is photo degradation caused by UV radiation is the most damaging, however, the synergistic contribution from others plays a significant part (Johnson and MaIntyre, 1996).

Wood contains fibrous structure of cellulose, hemicelluloses and a three dimensional network of lignin, as well as other components in small quantities. Wood is a material capable of absorbing sunlight and initiating photochemical reactions. Free radicals are involved in the active intermediates for degradative chain reactions which caused the change of colour in wood when exposed to light. Lignin has been found to be responsible for the absorption of light and the formation of free radicals, which subsequently lead to the formation of quinones that contribute to the discolouration reaction (Obataya et $a l, 1998)$. Free radicals rapidly interact with oxygen to produce hydroperoxide impurities, which in turn are easily decomposed to produce chromophoric groups, such as conjugated carbonyl and carboxyl groups. In recent years, the growth of the wood product industries has been accompanied by a significant expansion in the outdoor application of the material which has drawn attention in research for the protection of the appearances of the wood and the physical properties of the surface from weathering reactions. This study is therefore designed to evaluate the performance of Teak wood exposed to outdoor weather conditions. The parameters tested were percentage shrinkage, surface splitting and checking as well as colour changes in both radial and tangential directions

\section{MATERIALS AND METHODS}

Test pieces of wood measuring $20 \mathrm{~mm}$ x $20 \mathrm{~mm}$ x 40 $\mathrm{mm}$ were used for the evaluation of weathering characteristics of Teak wood exposed to outdoor weather conditions. The selection of test samples was done using the systematic sampling technique. A total of one hundred and sixty two test samples were used for the study. These test pieces of wood samples 
were obtained from six trees each of an even aged stand comprising three age classes of 15, 20 and 25year old Teak wood respectively.

The moisture content of the samples was computed using the formula:

M.C =

Initial wt. of samples - Oven dry wt. of samples x 100 Oven dry weight of samples

The test samples were thereafter exposed to outdoor conditions for a period of 12 months and observed for dimensional changes such as percentage shrinkage, surface checking, surface splitting, and colour changes in both radial and tangential directions. The test samples were observed for dimensional changes every two weeks for 12 months. Changes in percentage shrinkage were measured using digital caliper while changes in surface checking, surface splitting and colour variations were visually observed and recorded in accordance with standard procedure (William et al, 2000).

\section{RESULTS AND DISCUSSION}

Percentage Shrinkage of Weathered Teak Wood: The mean values obtained for percentage shrinkage of weathered Teak in the radial directions were 1.51, 1.30 and $0.73 \%$ while the mean values obtained in the tangential directions were $3.14,2.23$ and $1.27 \%$ for ages 15, 20 and 25-year old Teak wood respectively (Table 1). The trend in the variations of percentage shrinkage of weathered Teak exposed to outdoor conditions from base to top is presented (Figures 1 and 2). Analysis of variance carried out to test for significant differences among the sampled trees in radial and longitudinal positions showed that there were significant differences in percentage shrinkage of weathered Teak among the three age classes, the radial positions and the longitudinal position at 0.05 probability levels (Table 2). Teak wood exposed to outdoor weather conditions either lost or gained moisture depending on the relative humidity of the environment until stable equilibrium moisture content was attained. There was a general decrease in percentage shrinkage with increase in the age of the tree, from 15 through 20 to 25 -year old Teak wood respectively. The observed changes in dimensional stability associated with increase in the age of the tree could be due to changes brought about by increase in cell size and percentage of the early wood.

Percentage shrinkage generally increased from the tree base to the top and from the innerwood to the outerwood. This pattern of variations correlates earlier findings (Mottonen and Luostarinen 2006; Seralde 2006). The authors attributed variability in dimensional changes of wood to decrease in specific gravity along the tree bole. The increased in percentage shrinkage from the inner wood to the outer wood observed in this study is similar to the published work of Shupe et al (1995a and 1995b) for yellow Poplar. Koubaa et al (1998) also reported increase in dimensional changes along the tangential surfaces of some hybrid Poplar clones. They concluded that the dimensions of the inner wood shrink less than the outer wood in both radial and tangential directions due to greater amount of extractives in the inner wood and the increase in specific gravity from the inner wood to the outer wood.

Evaluation of Surface Splitting, Surface Checking and Colour Changes in Weathered Teak wood: The results of the evaluation of surface splitting, surface checking and colour changes in Teak wood exposed to outdoor weather conditions are presented (Tables 3,4 and 5). The observations made on the physical changes of the study samples were based on standard procedure (William et al, 2000) as follows: 10 (No Change), 8-9 (Slight Change), 5-7 (Moderate Change), 1- 4 (Severe Change)

Based on the above numerical values, there were no observed physical changes for surface splitting at both the radial and tangential directions among the three age classes of 15, 20 and 25- year old Teak wood respectively (Table 3). Slight physical changes were observed for surface checking in the radial directions for 15 and 20- year old Teak wood. There were however, no observed physical changes in surface checking for the 25- year old Teak wood at the radial direction (Table 4). At the tangential directions, moderate physical changes in surface checking were observed for 15 and 20-year old Teak wood while slight physical changes were observed in surface checking for the 25-year old Teak wood (Table 
Table 1: Mean Shrinkage values (\%) of Weathered Teak in the Radial and Tangential directions

\begin{tabular}{|c|c|c|c|c|c|c|}
\hline & & & Sampling & Height (\%) & & \\
\hline $\begin{array}{c}\text { Age } \\
\text { (Years) }\end{array}$ & $\begin{array}{c}\text { Wood } \\
\text { Properties }\end{array}$ & $\begin{array}{c}\text { Radial } \\
\text { Position }\end{array}$ & $\begin{array}{l}\text { Base }(10 \%) \\
\text { Mean } \pm \text { SD }\end{array}$ & $\begin{array}{l}\text { Middle( } 50 \%) \\
\text { Mean } \pm \text { SD }\end{array}$ & $\begin{array}{l}\text { Top }(90 \%) \\
\text { Mean } \pm \text { SD }\end{array}$ & $\begin{array}{l}\text { Pooled Mean } \\
\text { Mean } \pm \text { SD }\end{array}$ \\
\hline 15 & $\begin{array}{l}\text { Radial } \\
\text { directions } \\
(\%)\end{array}$ & $\begin{array}{l}\text { Outerwood } \\
\text { Middlewood } \\
\text { Innerwood } \\
\text { PooledMean }\end{array}$ & $\begin{array}{l}1.52 \pm 0.19^{\mathrm{b}} \\
1.38 \pm 0.16^{\mathrm{d}} \\
1.26 \pm 0.14^{\mathrm{d}} \\
1.39 \pm 0.13\end{array}$ & $\begin{array}{l}1.65 \pm 0.14^{\mathrm{b}} \\
1.50 \pm 0.15^{\mathrm{d}} \\
1.34 \pm 0.14^{\mathrm{d}} \\
1.49 \pm 0.17\end{array}$ & $\begin{array}{l}1.81 \pm 0.11^{\mathrm{a}} \\
1.64 \pm 0.13^{\mathrm{c}} \\
1.51 \pm 0.15^{\mathrm{b}} \\
1.65 \pm 0.15\end{array}$ & $\begin{array}{l}1.66 \pm 0.15 \\
1.51 \pm 0.13 \\
1.36 \pm 0.13 \\
1.51 \pm 0.13\end{array}$ \\
\hline 20 & & $\begin{array}{l}\text { Outerwood } \\
\text { Middlewood } \\
\text { Innerwood } \\
\text { Pooled Mean }\end{array}$ & $\begin{array}{l}1.37 \pm 0.13^{\mathrm{c}} \\
1.18 \pm 0.13^{\mathrm{c}} \\
1.23 \pm 0.24^{\mathrm{c}} \\
1.21 \pm 0.15\end{array}$ & $\begin{array}{l}1.44 \pm 0.16^{\mathrm{b}} \\
1.27 \pm 0.13^{\mathrm{bc}} \\
1.16 \pm 0.14^{\mathrm{c}} \\
1.29 \pm 0.14\end{array}$ & $\begin{array}{l}1.58 \pm 0.15^{\mathrm{da}} \\
1.37 \pm 0.16^{\mathrm{c}} \\
1.27 \pm 0.16^{\mathrm{bc}} \\
1.41 \pm 0.16\end{array}$ & $\begin{array}{l}1.47 \pm 0.11 \\
1.27 \pm 0.09 \\
1.17 \pm 0.10 \\
1.30 \pm 0.10\end{array}$ \\
\hline 25 & & $\begin{array}{l}\text { Outerwood } \\
\text { Middlewood } \\
\text { Innerwood } \\
\text { Pooled Mean }\end{array}$ & $\begin{array}{l}0.72 \pm 0.16^{\mathrm{b}} \\
0.58 \pm 0.15^{\mathrm{bd}} \\
0.48 \pm 0.17^{\mathrm{e}} \\
0.59 \pm 0.12\end{array}$ & $\begin{array}{l}0.85 \pm 0.19^{\mathrm{bc}} \\
0.74 \pm 0.19^{\mathrm{ef}} \\
0.60 \pm 0.18^{\mathrm{e}} \\
0.73 \pm 0.13\end{array}$ & $\begin{array}{l}0.95 \pm 0.15^{\mathrm{a}} \\
0.87 \pm 0.17^{\mathrm{cf}} \\
0.75 \pm 0.16^{\mathrm{ef}} \\
0.86 \pm 0.10\end{array}$ & $\begin{array}{l}0.84 \pm 0.12 \\
0.73 \pm 0.15 \\
0.61 \pm 0.14 \\
0.73 \pm 0.14\end{array}$ \\
\hline 15 & $\begin{array}{l}\text { Tangential } \\
\text { directions } \\
(\%)\end{array}$ & $\begin{array}{l}\text { Outerwood } \\
\text { Middlewood } \\
\text { Innerwood } \\
\text { Pooled Mean }\end{array}$ & $\begin{array}{l}3.20 \pm 0.06^{\mathrm{cd}} \\
3.08 \pm 0.08^{\mathrm{f}} \\
2.80 \pm 0.11^{\mathrm{h}} \\
3.03 \pm 0.20\end{array}$ & $\begin{array}{l}3.29 \pm 0.06^{\mathrm{bd}} \\
3.16 \pm 0.05^{\mathrm{ce}} \\
2.94 \pm 0.10^{\mathrm{fh}} \\
3.13 \pm 0.18\end{array}$ & $\begin{array}{l}3.43 \pm 0.07^{\mathrm{a}} \\
3.27 \pm 0.11^{\mathrm{ad}} \\
3.12 \pm 0.18^{\mathrm{eg}} \\
3.28 \pm 0.15\end{array}$ & $\begin{array}{l}3.31 \pm 0.12 \\
3.17 \pm 0.10 \\
2.95 \pm 0.16 \\
3.14 \pm 0.13\end{array}$ \\
\hline 20 & & $\begin{array}{l}\text { Outerwood } \\
\text { Middlewood } \\
\text { Innerwood } \\
\text { Pooled Mean }\end{array}$ & $\begin{array}{l}2.34 \pm 0.10^{\mathrm{b}} \\
2.17 \pm 0.06^{\mathrm{c}} \\
1.82 \pm 0.12^{\mathrm{f}} \\
2.11 \pm 0.26\end{array}$ & $\begin{array}{l}2.44 \pm 0.12^{\mathrm{bd}} \\
2.28 \pm 0.07^{\mathrm{bc}} \\
1.97 \pm 0.17^{\mathrm{e}} \\
2.23 \pm 0.24\end{array}$ & $\begin{array}{l}2.54 \pm 0.12^{\mathrm{a}} \\
2.42 \pm 0.07^{\mathrm{cd}} \\
2.09 \pm 0.20^{\mathrm{d}} \\
2.35 \pm 0.24\end{array}$ & $\begin{array}{l}2.44 \pm 0.10 \\
2.29 \pm 0.13 \\
1.96 \pm 0.13 \\
2.23 \pm 0.12\end{array}$ \\
\hline 25 & & $\begin{array}{l}\text { Outerwood } \\
\text { Middlewood } \\
\text { Innerwood } \\
\text { Pooled Mean }\end{array}$ & $\begin{array}{l}1.37 \pm 0.12^{\mathrm{b}} \\
1.04 \pm 0.14^{\mathrm{eg}} \\
0.88 \pm 0.18^{\mathrm{g}} \\
1.10 \pm 0.25\end{array}$ & $\begin{array}{l}1.50 \pm 0.11^{\mathrm{b}} \\
1.23 \pm 0.15^{\mathrm{df}} \\
0.99 \pm 0.14^{\mathrm{e}} \\
1.24 \pm 0.25\end{array}$ & $\begin{array}{l}1.60 \pm 0.12^{\mathrm{a}} \\
1.48 \pm 0.12^{\mathrm{b}} \\
1.29 \pm 0.13^{\mathrm{bf}} \\
1.46 \pm 0.16\end{array}$ & $\begin{array}{l}1.49 \pm 0.12 \\
1.25 \pm 0.22 \\
1.05 \pm 0.21 \\
1.27 \pm 0.18\end{array}$ \\
\hline
\end{tabular}

Each value is the mean and standard deviation of 6 replicates sampled trees of Teak Means of the same age with different superscript are significantly different $(p<0.05)$

Table 2: Analysis of Variance for Percentage Shrinkage of Weathered Teak

\begin{tabular}{llrc}
\hline Source of Variation & df & Radial Shrinkage & Tangential Shrinkage \\
\hline Age & 2 & $287.96^{*}$ & $1939.57^{*}$ \\
Height & 2 & $23.97^{*}$ & $33.75^{*}$ \\
Radial Position & 2 & $26.91^{*}$ & $76.78^{*}$ \\
Age*Height & 4 & $0.69^{\mathrm{ns}}$ & $3.17^{\mathrm{ns}}$ \\
Age*Radial Position & 4 & $0.42^{\mathrm{ns}}$ & $1.57^{\mathrm{ns}}$ \\
Radial Position*Height & 4 & $0.33^{\mathrm{ns}}$ & $1.15^{\mathrm{ns}}$ \\
Age*Radial Position*Height & 8 & $0.29^{\mathrm{ns}}$ & $1.26^{\mathrm{ns}}$ \\
Error & 135 & & \\
Total & 161 & & \\
\hline
\end{tabular}

*significant $(\mathrm{p}<0.05)$ probability level $\mathrm{ns}=$ not significant $(\mathrm{p}<0.05)$ probability level 


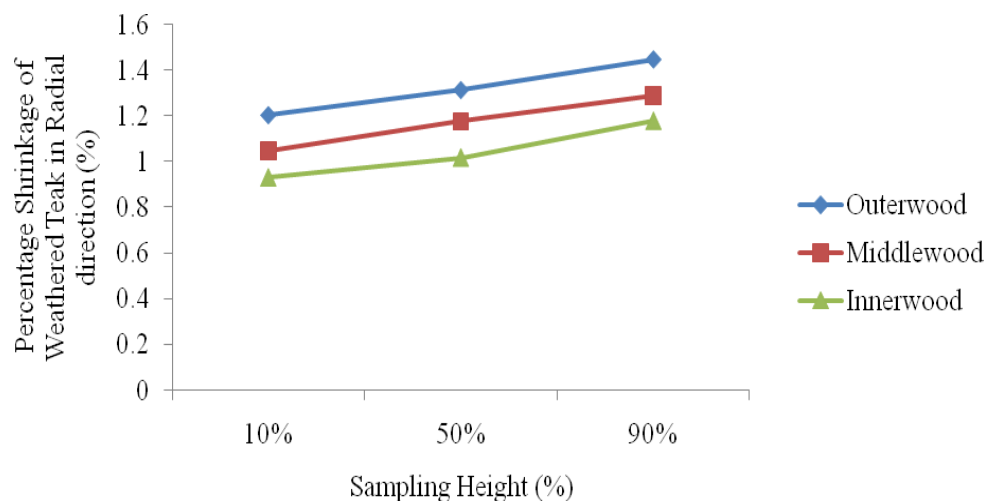

Fig.1: Axial variation in Percentage Shrinkage of Weathered Teak wood in the Radial direction

The weathering performance evaluation of the studied samples in relation to dimensional changes showed that Teak wood is resistant to end splitting and surface checking in both radial and tangential surfaces. This observation is similar to the findings of Wang (1990) who reported that, teak wood was rank as one of the species most resistant to surface checking and end grain splitting. William et al (2000) also reported that Teak has the least surface checking and warping after cyclic wetting when compared to other tropical hard wood species.

The effects of weathering on colour changes observed among the three age classes were quite obvious. All the study samples irrespective of the tree age as well as the longitudinal and radial positions from where the wood samples were collected have severe colour changes in both the radial and tangential directions (Table 5).
Discolouration and loss of brightness was observed for all the study samples irrespective of the tree age. Radial and tangential surfaces of the study samples showed some colour changes as a result of outdoor exposure to weather conditions. The observed changes in the colour of Teak wood can be related to the decomposition of lignin in the surface wood cells as a result of photochemical degradation of the exposed wood surface from sunlight (Feist, 1990). These changes in colour and brightness were readily observed in all the wood samples changing gradually from the fine grain colour to yellow and finally grey. This similar observation were made by Hon and Feist (1986), when they exposed four hardwoods (red oak, white oak, yellow oak and sweet gum) to outdoor weathering and artificial UV light. They reported that discolouration and loss of brightness were observed for all the species regardless of their exposure conditions.

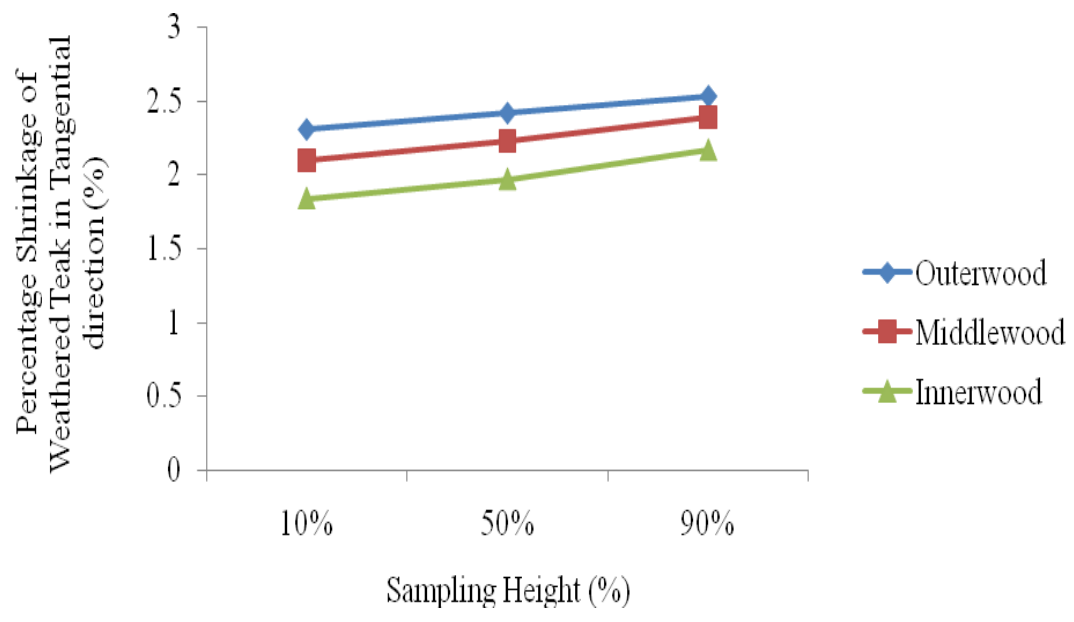

Fig.2: Axial variation in Percentage Shrinkage of Weathered Teak Wood in the Tangential direction 
Table 3: Ranking values of surface splitting in the Radial and Tangential directions of Weathered Teak in Relation to Age

\begin{tabular}{|c|c|c|c|c|c|}
\hline & & & Sampling & Height (\%) & \\
\hline $\begin{array}{l}\text { Age } \\
\text { (Years) }\end{array}$ & $\begin{array}{l}\text { Wood } \\
\text { Properties }\end{array}$ & $\begin{array}{l}\text { Radial } \\
\text { Position }\end{array}$ & Base $(10 \%)$ & Middle ( $50 \%$ ) & Top (90\%) \\
\hline 15 & $\begin{array}{l}\text { Radial } \\
\text { direction }\end{array}$ & $\begin{array}{l}\text { Outerwood } \\
\text { Middlewood } \\
\text { Innerwood }\end{array}$ & $\begin{array}{l}10 \\
10 \\
10\end{array}$ & $\begin{array}{l}10 \\
10 \\
10\end{array}$ & $\begin{array}{l}10 \\
10 \\
10\end{array}$ \\
\hline 20 & & $\begin{array}{l}\text { Outerwood } \\
\text { Middlewood } \\
\text { Innerwood }\end{array}$ & $\begin{array}{l}10 \\
10 \\
10\end{array}$ & $\begin{array}{l}10 \\
10 \\
10\end{array}$ & $\begin{array}{l}10 \\
10 \\
10\end{array}$ \\
\hline 25 & & $\begin{array}{l}\text { Outerwood } \\
\text { Middlewood } \\
\text { Innerwood }\end{array}$ & $\begin{array}{l}10 \\
10 \\
10\end{array}$ & $\begin{array}{l}10 \\
10 \\
10\end{array}$ & $\begin{array}{l}10 \\
10 \\
10\end{array}$ \\
\hline 15 & $\begin{array}{l}\text { Tangential } \\
\text { Direction }\end{array}$ & $\begin{array}{l}\text { Outerwood } \\
\text { Middlewood } \\
\text { Innerwood }\end{array}$ & $\begin{array}{l}10 \\
10 \\
10\end{array}$ & $\begin{array}{l}10 \\
10 \\
10\end{array}$ & $\begin{array}{l}10 \\
10 \\
10\end{array}$ \\
\hline 20 & & $\begin{array}{l}\text { Outerwood } \\
\text { Middlewood } \\
\text { Innerwood }\end{array}$ & $\begin{array}{l}10 \\
10 \\
10\end{array}$ & $\begin{array}{l}10 \\
10 \\
10\end{array}$ & $\begin{array}{l}10 \\
10 \\
10\end{array}$ \\
\hline 25 & & $\begin{array}{l}\text { Outerwood } \\
\text { Middlewood } \\
\text { Innerwood }\end{array}$ & $\begin{array}{l}10 \\
10 \\
10\end{array}$ & $\begin{array}{l}10 \\
10 \\
10\end{array}$ & $\begin{array}{l}10 \\
10 \\
10\end{array}$ \\
\hline
\end{tabular}

Conclusion: Teak wood on exposure to outdoor weather conditions shrinks as it loses moisture and swells as it gain moisture in response to relative humidity of the environment until stable equilibrium moisture content was attained. Percentage shrinkage of weathered Teak wood increased from the tree base to the top and also from the inner wood to the outerwood. Percentage shrinkage however decreases progressively with increase in the age of the tree. Teak wood exposed to outdoor weather conditions were resistant to end splitting and surface checking in both radial and tangential directions among the three age classes of the study samples. Discolouration and loss of brightness was observed for all the study samples in both radial and tangential directions irrespective of the tree age. The observed changes in the colour of Teak wood were associated to the decomposition of lignin in the surface wood cells as a result of photochemical degradation of the exposed wood surface from sunlight. Teak wood of older age classes is therefore recommended for use in outdoor applications as a result of its less shrinkage and high resistance to end splitting and surface checking on exposure to outdoor weather conditions. This study has therefore shown that, plantation grown Tectona grandis wood from Edo State could perform favourably when used as structural material in outdoor weather conditions.

\section{REFERENCES}

de la Caba, K; Guerrero, P; del Rio, M; Mondragon, I. (2007). Weathering behavior of wood- faced Construction Material. Construction and Building Materials 21: 1288-1294.

Feist, W.C. (1990). Weathering performance of painted wood pretreated with waterRepellent preservative. Forest Products Journal 40(7/8): 21-26.

Johnson, R. and Mclntyre, R. (1996). Analysis of test methods for UV durability predictions of Polymer coating. Prog. Org. Coat 27(1-4): 95-106.

Koubaa, A; Hernandez, R.E; Beaudoin, M. and Poliquin, J. (1998). Interclonal, Intraclonal and within-tree variation in fiber length of poplar hybrid clones. Wood and Fiber Sci. 30 (1): 40-47. 
Mahmoud, A.A; Eissa, A.M.P; Omar, M.S; EL-Sawy, A.A; and Shaaban, A.F. (2001). Improvement of white pine wood properties by impregnation with unsaturated Polyesters in admixture with styrene. J. Appl. Polym. Sci. 82 (6): 1410-1416.

Mottonen, V. and Luostarinen, K. (2006). Variations in density and shrinkage of Birch(Betula pendula Roth) timber from plantation and naturally regenerated forest. Forest Products Journal 56 (1): 34 - 39.

Seralde, T.C. (2006). Evaluation of wood properties of genetically modified trees. Masters thesis. Wood and Fiber Science, Raleigh, North Carolina.

Shupe, T.F; Choog, E.T. and Gibson, M.D. (1995a). Differences in moisture content and Shrinkage between outer wood, middle wood and core wood of two yellow Poplar trees. Forest Products Journal 45 (9): 85 - 90.

Shupe, T.F; Choog, E.T. and Gibson, M.D. (1995b). Differences in moisture content and and shrinkage between inner wood and outer wood of a single cotton wood tree. Forest Products Journal 45 (10): 89 92.

Obataya, E; Norimoto, M; Gril, J. (1998). The effects of absorbed water on dynamic mechanical Properties of wood. Polymer 39 (14): 3059-3064.

Wang, S.Y.(1990). Reduction of mechanical properties of seventeen Taiwan native wood species subjected to seven years exposure in an outdoor environment. Mokuzai Gakkaishi 36 (1): 69-77.

William, R.S; Miller, R. and Gangstad J

. (2000).Characteristics of ten tropical hardwoods from certified forests in Bolivia. Part 1 weathering characteristics and dimensional change. 618-626 pp.

Table 4: Ranking values of surface checking in the Radial and Tangential directions of Weathered Teak in Relation to Age

\begin{tabular}{|c|c|c|c|c|c|}
\hline & & & Sampling & $\begin{array}{l}\text { Height } \\
(\%)\end{array}$ & \\
\hline $\begin{array}{l}\text { Age } \\
\text { (Years) }\end{array}$ & $\begin{array}{l}\text { Wood } \\
\text { Properties }\end{array}$ & $\begin{array}{l}\text { Radial } \\
\text { Position }\end{array}$ & $\begin{array}{l}\text { Base ( } 10 \\
\%)\end{array}$ & $\begin{array}{l}\text { Middle } \\
(50 \% \\
)\end{array}$ & $\begin{array}{l}\text { Top } \\
(90 \\
\%)\end{array}$ \\
\hline 15 & $\begin{array}{l}\text { Radial } \\
\text { Surface }\end{array}$ & $\begin{array}{l}\text { Outerwood } \\
\text { Middlewood } \\
\text { Innerwood }\end{array}$ & $\begin{array}{l}8 \\
8 \\
8\end{array}$ & $\begin{array}{l}8 \\
8 \\
8\end{array}$ & $\begin{array}{l}8 \\
8 \\
8\end{array}$ \\
\hline 20 & & $\begin{array}{l}\text { Outerwood } \\
\text { Middlewood } \\
\text { Innerwood }\end{array}$ & $\begin{array}{l}9 \\
9 \\
9\end{array}$ & $\begin{array}{l}9 \\
9 \\
9\end{array}$ & $\begin{array}{l}9 \\
9 \\
9\end{array}$ \\
\hline 25 & & $\begin{array}{l}\text { Outerwood } \\
\text { Middlewood } \\
\text { Innerwood }\end{array}$ & $\begin{array}{l}10 \\
10 \\
10\end{array}$ & $\begin{array}{l}10 \\
10 \\
10\end{array}$ & $\begin{array}{l}10 \\
10 \\
10\end{array}$ \\
\hline 15 & $\begin{array}{l}\text { Tangential } \\
\text { Surface }\end{array}$ & $\begin{array}{l}\text { Outerwood } \\
\text { Middlewood } \\
\text { Innerwood }\end{array}$ & $\begin{array}{l}6 \\
6 \\
6\end{array}$ & $\begin{array}{l}5 \\
5 \\
5\end{array}$ & $\begin{array}{l}5 \\
5 \\
5\end{array}$ \\
\hline 20 & & $\begin{array}{l}\text { Outerwood } \\
\text { Middlewood } \\
\text { Innerwood }\end{array}$ & $\begin{array}{l}7 \\
7 \\
7\end{array}$ & $\begin{array}{l}6 \\
6 \\
6\end{array}$ & $\begin{array}{l}6 \\
6 \\
6\end{array}$ \\
\hline 25 & & $\begin{array}{l}\text { Outerwood } \\
\text { Middlewood } \\
\text { Innerwood }\end{array}$ & $\begin{array}{l}9 \\
9 \\
9\end{array}$ & $\begin{array}{l}8 \\
8 \\
8\end{array}$ & $\begin{array}{l}8 \\
8 \\
8\end{array}$ \\
\hline
\end{tabular}

All evaluations used a scale of 10 (No Change), 8-9 (Slight Change), 5-7 (Moderate Change) 1-4 (Severe Change)

Table 5: Effects of Weathering on colour changes in the Radial and Tangential directions of

\begin{tabular}{|c|c|c|c|c|c|}
\hline & & & Sampling & $\begin{array}{l}\text { Height } \\
(\%)\end{array}$ & \\
\hline $\begin{array}{l}\text { Age } \\
\text { (Years) }\end{array}$ & $\begin{array}{l}\text { Wood } \\
\text { Properties }\end{array}$ & $\begin{array}{l}\text { Radial } \\
\text { Position }\end{array}$ & Base ( $10 \%)$ & $\begin{array}{l}\text { Middle } \\
\text { ( } 50 \%\end{array}$ & $\begin{array}{l}\text { Top ( } 90 \\
\%)\end{array}$ \\
\hline \multirow[t]{3}{*}{15} & Radial & Outerwood & 2 & 2 & 1 \\
\hline & Surface & Middlewood & 2 & 2 & 1 \\
\hline & & Innerwood & 2 & 2 & 1 \\
\hline \multirow[t]{3}{*}{20} & & Outerwood & 3 & 3 & 2 \\
\hline & & Middlewood & 3 & 3 & 2 \\
\hline & & Innerwood & 3 & 3 & 2 \\
\hline \multirow[t]{4}{*}{25} & & Outerwood & 3 & 3 & 3 \\
\hline & & Middlewood & 3 & 3 & 3 \\
\hline & & Innerwood & 3 & 3 & 3 \\
\hline & & & & & 3 \\
\hline \multirow[t]{3}{*}{15} & Tangential & Outerwood & 2 & 2 & 1 \\
\hline & Surface & Middlewood & 2 & 2 & 1 \\
\hline & & Innerwood & 2 & 2 & 1 \\
\hline \multirow[t]{3}{*}{20} & & Outerwood & 3 & 3 & 2 \\
\hline & & Middlewood & 3 & 3 & 2 \\
\hline & & Innerwood & 3 & 3 & 2 \\
\hline \multirow[t]{3}{*}{25} & & Outerwood & 3 & 3 & 3 \\
\hline & & Middlewood & 3 & 3 & 3 \\
\hline & & Innerwood & 3 & 3 & 3 \\
\hline
\end{tabular}

All evaluations used a scale of 10 (No Change), 8 - 9 (Slight Change), 5 - 7 (Moderate Change) 1 - 4 (Severe Change) 